\title{
A Pediculid Case: Autosensitization Dermatitis Caused by Pediculosis Capitis
}

\section{Bir Pedikülid Olgusu: Pedikülozis Kapitisin Neden Olduğu Otosensitizasyon Dermatiti}

\author{
Zennure Takcı', Özlem Tekin'1, Ayşe Serap Karadağ² \\ 1'Department of Skin and Venereal Diseases, Ministry of Health. Keçiören Ankara Training and Research Hospital, Ankara, Turkey \\ ${ }^{2}$ Department of Skin and Venereal Diseases, Faculty of Medicine, Van University, Van, Turkey
}

\begin{abstract}
Pediculosis capitis is a worldwide infestation caused by Pediculus humanus capitis ectoparasite that only lives on the hairs of the scalp. As a result of severe itching excoriation, secondary bacterial infection, cervical and occipital lymphadenopathy are seen frequently where, sometimes bite reaction, viral exanthema mimicking hypersensitivity eruption and conjunctivitis may occur. Hereby, with the presentation of a quite rarely seen pediculid case, characterized with common autosensitization dermatitis as an -id reaction to pediculosis capitis, the importance of exploring the source of the infection and/or infestation on the patients who have presentd with generalized pruritic maculopapular eruption, is emphasized. (Turkiye Parazitol Derg 2012; 36: 185-7)
\end{abstract}

Key Words: Pediculosis capitis, autosensitization dermatitis, pediculid

Received: 24.11.2011

Accepted: 07.05.2012

\section{ÖZET}

Pedikülozis kapitis Pediculus humanus capitis ektoparazitinin saçlı deride yerleşimi sonucu ortaya çıkan bir enfestasyondur. Şiddetli kaşıntı sonucu ekskoriyasyon, sekonder bakteriyel enfeksiyon, servikal ve oksipital lenfadenopati sıkça görülürken bazen ısırık reaksiyonu, viral egzantemi taklit edebilen hipersensitive döküntüsü ve konjonktivite neden olabilir. Burada pedikülozis kapitis'in neden olduğu, yaygın otosensitizasyon dermatiti ile karakterize oldukça nadir görülen bir pedikülid olgusu sunularak, generalize pruritik makülopapüler döküntü ile başvuran hastalarda enfeksiyon ve enfestasyon odağı taramasının önemi vurgulanmak istenmiştir. (Turkiye Parazitol Derg 2012; 36: 185-7)

Anahtar Sözcükler: Pedikülozis kapitis, otosensitizasyon dermatiti, pedikülid

Geliş Tarihi: 24.11.2011

Kabul Tarihi: 07.05.2012

\section{INTRODUCTION}

Pediculosis capitis is a worldwide public health problem caused by Pediculosis humanus capitis. The ectoparasitic infestation can be seen in all ages, commonly on girls with an age range of 3-12 years, and most frequently infests by head-to-head close contact (1). Rarely the course of the disease is asymptomatic but usually causes severe itching.
Excoriation related with itching, secondary bacterial infection, cervical and occipital lymphadenopathy can frequently accompany the infestation $(1,2)$. Autosensitization dermatitis is an acute generalized cutaneous eczematous reaction, developing a distance away from a primary inflammatory focus (3). Herein, a rarely seen pediculid case, which is an autosensitization dermatitis developed as an-id reaction to pediculosis infestation, is presented.

This study was presented as a poster at the Days Aegean Dermatology, 4-8 May 2011.

Address for Correspondence / Yazışma Adresi: Dr. Zennure Takcı, Department of Skin and Venereal Diseases, Ministry of Health. Keçiören Ankara Training and Research Hospital, Ankara, Turkey Phone: +90 3123569000 E-mail: drzennure80@yahoo.com doi:10.5152/tpd.2012.44 


\section{CASE REPORT}

A 72-year old female presented at our outpatient clinic suffering from a severe pruritic rash all over her body which started approximately 6 months earlier. The patient had previously applied to other clinics because of the severe itching and a skin biopsy was taken with pre-diagnosis of atopic dermatitis, bullous pemphigoid and Duhring disease. While the histopathological examination revealed spongiotic dermatitis, no immune deposition was identified in the immunofluorescent analysis. The patient, who had partial benefit from topical steroids and oral antihistaminics, was expressing that her complaints were gradually increasing. The patient, living alone in low socio-economical conditions, had asthma and a history of hypertension in her background and was not on any regular systemic medication. The physical examination was normal apart from the $1-1.5 \mathrm{~cm}$ mobile lymphadenopathies at the cervical and occipital zones. On dermatological examination, pale erythematous, maculopapular patches, excoriated papules and linear excoriations were seen on the entire body, more significantly on the proximal arm and leg segments (Figure 1). On the scalp, especially in the occipital and retro-

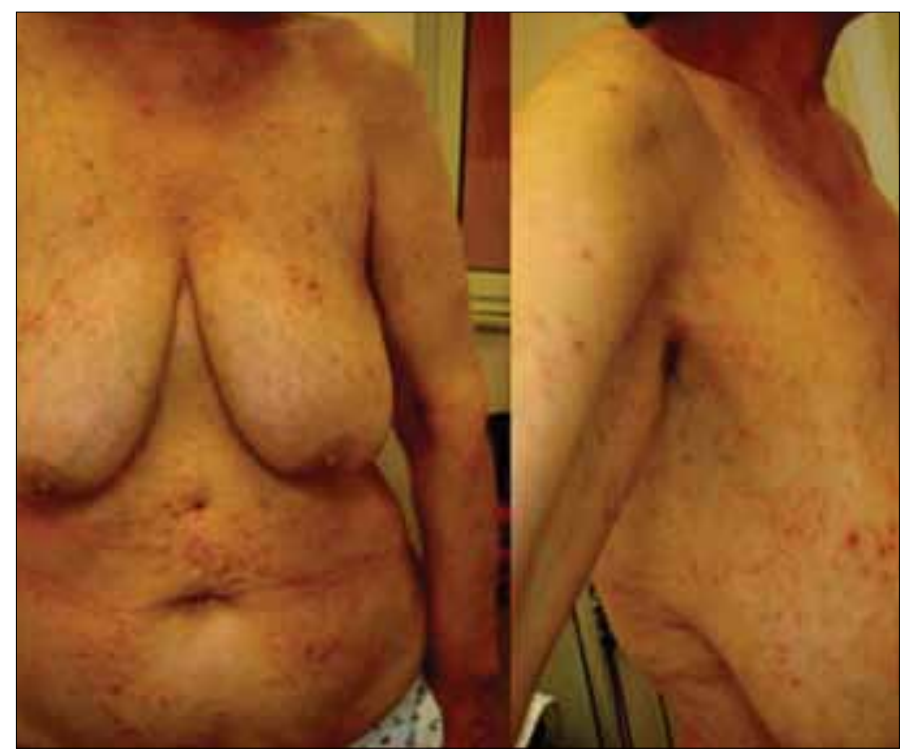

Figure 1. Eczematous maculopapular eruption on the body

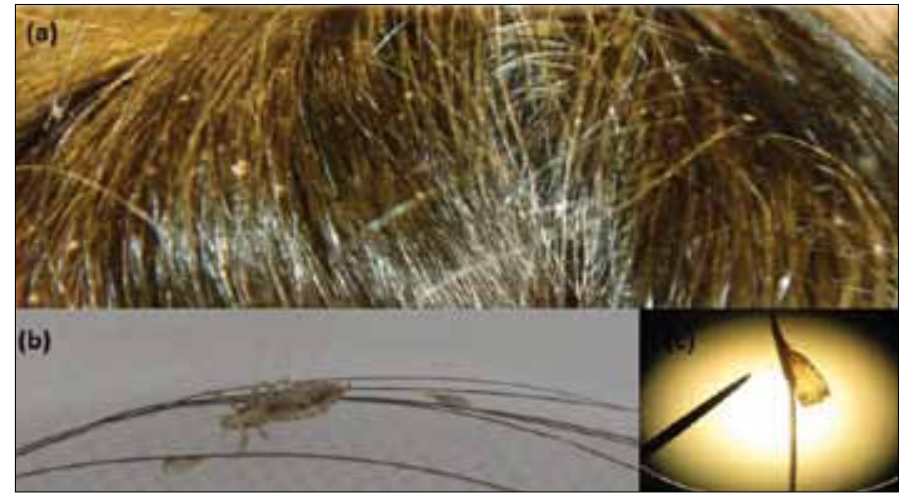

Figure 2. (a) Nits are present on the hair of the scalp. (b) Microscopic view of a head louse and nits. (c) Head louse nit attached to hair shaft auricular portions, many nits attached to the hair roots and crawling lice were seen (Figure 2, 3). Laboratory tests were normal except for findings of iron deficiency anemia. On examination of a peripheral blood smear, there was no eosinophilia. The complaints of the patient have totally regressed with $1 \%$ permetrine hair lotion, intramuscular injection of 40 mg triamcinolone acetonide, topical corticosteroid and systemic antihistaminic treatments.

\section{DISCUSSION}

Pediculosis capitis is an infestation caused by Pediculus humanus capitis ectoparasite, a six legged parasite, nesting on the scalp (4). The most common symptom seen in the patients is itching on the scalp, appearing approximately 7-10 days after sensitivity to the parasite's saliva or excrement antigens $(4,5)$. Following the severe itching, excoriations, secondary bacterial infection, occipital or cervical lymphadenopathy might develop (1). Autosensitization dermatitis is an acute dermatitis appearing as itchy erythematous, maculopapular or papulovesicular lesions away from the primary inflammation focus (3). Although it is seen most frequently in leg ulcer patients, infections, trauma, irritant or allergic chemical substance contact and ionizing radiation may also cause irritation (6). Even though the etiology of the eczematous reaction is not known for certain, autosensitization developing against the epidermal antigens is emphasized (7). When being related with an infectious case, it is referred as dermatophytid, pediculid, bacterid or virusid in accordance with the etiologic factor (8). The pruritic rash related with pediculosis capitis was first defined by Ronchese in 1946 (9). Brenner and his colleagues were the ones who used the term of pediculid for the first time in 1984, by describing pruritic eruption related with pediculosis capitis (8). To our knowledge there are only 3 pediculid cases in the literature. While generalized pruritic skin-colored papules existed on 2 patients with pediculosis capitis, the other case was a bullous pediculid identified in a patient with pediculosis pubis $(8,10)$. Hereby, with the presentation of a rarely reported pediculid case, the importance of exploring infection or infestation focus explore in patients who present with generalized pruritic maculopapular eruption was emphasized, before considering any complicated diagnosis requiring advanced examinations.

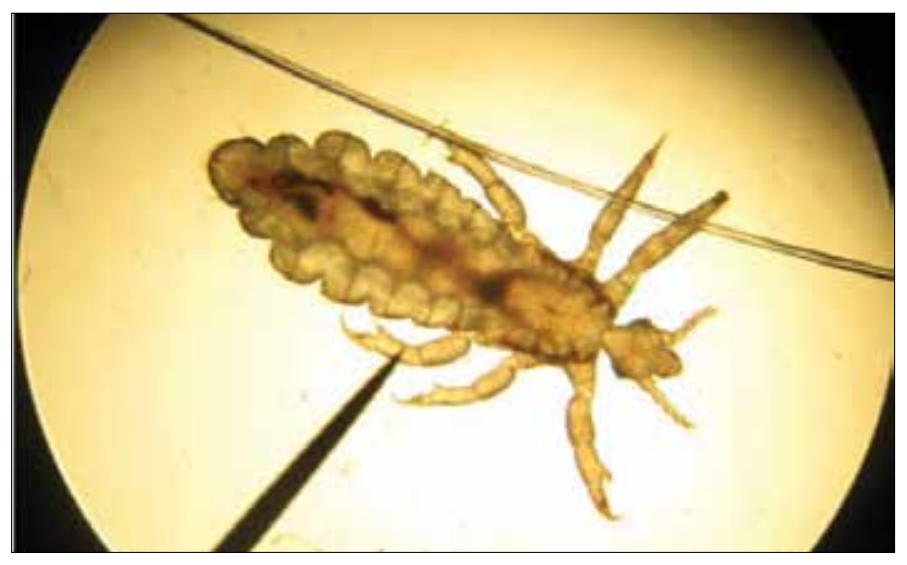

Figure 3. Microscopic view of a head louse 


\section{Conflict of Interest}

No conflict of interest was declared by the authors.

\section{REFERENCES}

1. Ko CJ, Elston DM. Pediculosis. J Am Acad Dermatol 2004; 50: 1-12. [CrossRef]

2. Bloomfield D. Head lice. Pediatr Rev 2002; 23: 34-5.[CrossRef]

3. Young AW Jr. Dynamics of autosensitization dermatitis; a clinical and microscopic concept of autoeczematization. AMA Arch Derm 1958; 77: 495-502.[CrossRef]

4. Leung AK, Fong JH, Pinto-Rojas A. Pediculosis capitis. J Pediatr Health Care 2005; 19: 369-73.[CrossRef]

5. Orion E, Matz H, Ruocco V, Wolf R. Parasitic skin infestations II, scabies, pediculosis, spider bites: unapproved treatments. Clin Dermatol 2002; 20: 618-25.[CrossRef]
6. Chang YT, Shen JJ, Wong WR, Yen HR. Alternative therapy for autosensitization dermatitis. Chang Gung Med J 2009; 32: 668-73.

7. Belsito DV. Autosensitization dermatitis. In: Wolff K, Goldsmith LG, Katz SI, Gilchrest BA, Paller AS, Leffell DJ, editors. Fitzpatrick's Dermatology in General Medicine. 7rd ed. New York: McGraw-Hill, 2008; 167-8.

8. Brenner S, Ophir J, Krakowski A. Pediculid. An unusual -id reaction to pediculosis capitis. Dermatologica 1984; 168: 189-91.[CrossRef]

9. Ronchese F. Generalized dermatitis from pediculosis capitis. New Engl J Med 1946; 234: 665-6.[CrossRef]

10. Brenner S, Yust I. Bullous eruption in a case of bullous pediculid. Cutis 1988; 41: 281. 